\title{
Fasting serum C-peptide is useful for initial classification of diabetes mellitus in children and adolescents
}

\author{
Min Jung Cho, MD', \\ Min Sun Kim, MD', \\ Chan Jong Kim, $\mathrm{MD}^{2}$, \\ Eun Young Kim, $\mathrm{MD}^{3}$, \\ Jong Duk Kim, MD", \\ Eun Young Kim, MD ${ }^{5}$, \\ Dae-Yeol Lee, MD ${ }^{1}$
}

'Department of Pediatrics, Chonbuk National University Medical School, Jeonju, ${ }^{2}$ Department of Pediatrics, Chonnam National University Medical School, Gwangju, ${ }^{3}$ Department of Pediatrics, Chosun University School of Medicine, Gwangju, ${ }^{4}$ Department of Pediatrics, Wonkwang University College of Medicine, Iksan, ${ }^{5}$ Department of Pediatrics, Kwangju Christian Hospital, Gwangju, Korea

Received: 5 June, 2014

Revised: 20 June, 2014

Accepted: 24 June, 2014

Address for correspondence:

Min Sun Kim, MD

Department of Pediatrics, Chonbuk

National University Hospital,

Chonbuk National University

Medical School, 20 Geonji-ro,

Deokjin-gu, Jeonju 561-712, Korea

Tel: +82-63-250-2573

Fax: +82-63-250-1464

E-mail: children@jbnu.ac,kr
Purpose: With rising obesity rates in children, it is increasingly difficult to differentiate between type 1 and type 2 diabetes mellitus (T1DM, T2DM) on clinical grounds alone. Using C-peptide as a method of classifying diabetes mellitus (DM) has been suggested. This study aimed to find a correlation between fasting C-peptide level and DM types in children and adolescents.

Methods: A total of 223 diabetic children, newly diagnosed at 5 hospitals between January 2001 and December 2012, were enrolled in this study. Initial DM classification was based on clinical and laboratory data including fasting C-peptide at diagnosis; final classification was based on additional data (pancreatic autoantibodies, human leukocyte antigen type, and clinical course).

Results: Of 223 diabetic children, 140 were diagnosed with T1DM (62.8\%) and the remaining 83 with T2DM (37.2\%). The mean serum C-peptide level was significantly lower in children with T1DM $(0.80 \mathrm{ng} / \mathrm{mL})$ than in children with T2DM $(3.91 \mathrm{ng} /$ $\mathrm{mL}$ ). Among 223 children, 54 had a serum C-peptide level $<0.6 \mathrm{ng} / \mathrm{mL}$; they were all diagnosed with T1DM. The proportion of children with T2DM increased in accordance with C-peptide level. Forty-nine of 223 children had a C-peptide level $>3.0 \mathrm{ng} / \mathrm{mL}$; 48 of them (97.9\%) were diagnosed with T2DM.

Conclusion: In this study, we found that if the C-peptide level was $<0.6 \mathrm{ng} / \mathrm{mL}$ at diagnosis, T2DM could be excluded; if C-peptide level was $>3.0 \mathrm{ng} / \mathrm{mL}$, a T1DM diagnosis is unlikely. This finding suggests that serum fasting C-peptide level is useful for classifying DM type at the time of diagnosis in youth.

Keywords: C-peptide, Classification, Diabetes mellitus, Child

\section{Introduction}

Diabetes mellitus (DM) is one of the most common chronic disorders in children and adolescents characterized by hyperglycemi ${ }^{1)}$. Major forms of DM are classified according to deficiency of insulin secretion from pancreatic $\beta$-cell damage (type $1 \mathrm{DM}$ [T1DM]) and a consequence of insulin resistance with various degrees of $\beta$-cell impairment (type $2 \mathrm{DM}$ [T2DM]). Before the 1980s, T1DM was the only form of DM considered prevalent in children and adolescents. However, recent reports show an increasing prevalence of T2DM in children and adolescents around the world ${ }^{2-4}$. With rising obesity rates in children, it is increasingly difficult to differentiate between T1DM and T2DM on clinical grounds alone. Beside clinical characteristics, serum insulin level, pancreatic autoantibodies, and human leukocyte antigen (HLA) typing may help differentiate the 2 types of DM, but these tests are not specific diagnostic tools. Furthermore, diabetes classification at diagnosis is very important for optimal treatment.

C-peptide reflects insulin secretion from pancreatic $\beta$ cells, and the amount of insulin 
secreted reflects the metabolic needs of the body. One of the major roles for measuring C-peptide in pediatric populations is to assist in the correct diagnosis of diabetes subtypes, which in turn determines appropriate management. C-peptide levels are usually elevated in children with T2DM at diagnosis in contrast to children with T1DM. Katz et al. ${ }^{5)}$ identified that a fasting C-peptide level at $0.85 \mathrm{ng} / \mathrm{mL}$ had $83 \%$ of sensitivity and $89 \%$ specificity for distinguishing pediatric T1DM from T2DM at diagnosis. Recently, a study conducted in Sweden reported that a random C-peptide level at diagnosis may help to classify DM type ${ }^{6)}$. It is also useful in T1DM to monitor disease course. In childhood-onset T1DM, most of patients are severely deficient within 2 or 3 years of diagnosis, whereas in T2DM and maturity-onset diabetes of youth (MODY), C-peptide levels persist ${ }^{7-9}$. C-peptide can be measured in blood (fasting or nonfasting) and urine, and there is a significant correlation between blood level and urinary C-peptide measures ${ }^{10)}$. Simpler methods for measuring C-peptide are now available to evaluate endogenous insulin secretion in routine clinical practice.

The aim of this study was to find a correlation between C-peptide level and types of DM and distribution of C-peptide level according to types of DM in children and adolescents.

\section{Materials and methods}

\section{Patients}

Two hundred and twenty-three children and adolescents with diabetes were included in this study. All patients had been diagnosed with diabetes between January 2001 and December 2012 and followed for at least one year at the Pediatric Endocrinology Departments of 5 hospitals located in the Jeonbuk and Jeonnam provinces in Korea. Exclusion criteria were: (1) known diabetes before this study; (2) follow-up period
$<1$ year; (3) younger than 3 months of age; and (4) highly suspected MODY based on family history. The Institutional Review of the Clinical Research Institute in each hospital approved the study protocol.

\section{Methods}

The clinical characteristics and laboratory data of the 223 patients were obtained by reviewing their medical records. The following laboratory data from time of diagnosis were included: plasma glucose, bicarbonate, C-peptide, hemoglobin Alc (HbAlc), pancreatic autoantibodies (anti-GAD, IAA, IA-2, and ICA 512), thyroid autoantibodies (antithyroid peroxidase antibodies, antimicrosomal antibodies, antithyroglobuin antibodies, thyroid-stimulating hormone receptor antibodies), and HLA typing. Fasting serum C-peptide level at diagnosis was measured using an immunofluorescence assay (Cobas e 601 analyzer, Japan Hitachi, Tokyo, Japan).

Diagnosis of diabetes is based on the following criteria: (1) symptoms of diabetes plus random plasma glucose level $\geq 200$ $\mathrm{mg} / \mathrm{dL}$, (2) fasting plasma glucose level $\geq 126 \mathrm{mg} / \mathrm{dL}$, or (3) 2 -hour postload glucose level $\geq 200 \mathrm{mg} / \mathrm{dL}$. Initial classification of diabetic types was based on clinical and laboratory characteristics including fasting serum C-peptide at diagnosis; final classification was based on additional data including pancreatic autoantibodies, HLA type, and clinical course. We use a same interval of C-peptide level on Swedish study ${ }^{6}$.

\section{Statistical analysis}

All variables were expressed as mean \pm standard deviation values or percentage. Statistical analyses were performed using SPSS ver. 12.0 (SPSS Inc., Chicago, IL, USA). Student $t$-test and one-way analysis of variance were used. Cross tabulation and

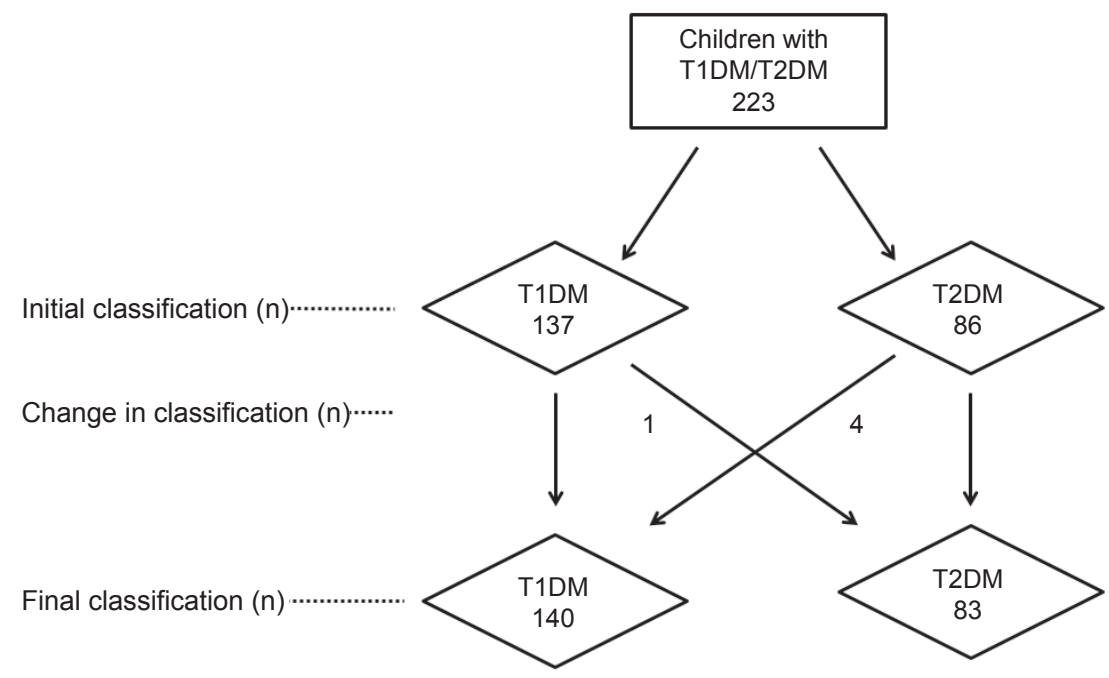

Fig. 1. Initial and final classification of 223 children with diabetes mellitus (DM). T1DM, type 1 DM; T2DM, type $2 \mathrm{DM}$. 
chi-square test was used for expecting positive rate. When there were indications of skewed distribution, Mann-Whitney $U$ test or Kruskall-Wallis test was used. Statistical significance was defined as a $P<0.05$ for all clinical and laboratory data.

\section{Results}

\section{Initial and final classification of 223 children with DM}

A total of 223 patients were identified with diabetes in 5

Table 1. Comparison of clinical and laboratory features of T1DM and T2DM

\begin{tabular}{|c|c|c|c|}
\hline Variable & T1DM & T2DM & $P$-value \\
\hline Age (yr) & $10.1 \pm 4.0$ & $14.0 \pm 2.3$ & $<0.001$ \\
\hline Body mass index $\left(\mathrm{kg} / \mathrm{m}^{2}\right)$ & $16.5 \pm 3.6$ & $24.6 \pm 4.2$ & $<0.001$ \\
\hline $\mathrm{HbA1c}(\%)$ & $12.1 \pm 2.2$ & $10.7 \pm 2.7$ & $<0.001$ \\
\hline $\mathrm{pH}$ & $7.3 \pm 0.1$ & $7.4 \pm 0.1$ & $<0.001$ \\
\hline $\mathrm{HCO}_{3}(\mathrm{mmol} / \mathrm{L})$ & $17.8 \pm 7.2$ & $23.7 \pm 2.6$ & $<0.001$ \\
\hline $\mathrm{BEECF}(\mathrm{mmol} / \mathrm{L})$ & $-7.8 \pm 8.6$ & $-1.0 \pm 2.7$ & $<0.001$ \\
\hline Glucose (mg/dL) & $367.2 \pm 215.0$ & $239.3 \pm 139.3$ & $<0.001$ \\
\hline C-peptide (ng/mL) & $0.80 \pm 0.6$ & $3.91 \pm 2.4$ & $<0.001$ \\
\hline Family history of T2DM (\%) & 29.5 & 57.3 & $<0.001$ \\
\hline Polydipsia (\%) & 90.6 & 43.8 & $<0.001$ \\
\hline Polyuria (\%) & 91.3 & 40.5 & $<0.001$ \\
\hline Weight loss (\%) & 85.2 & 35.0 & $<0.001$ \\
\hline DKA $(\%)^{a)}$ & 38.6 & 2.4 & $<0.001$ \\
\hline Thyroid Ab (\%) & 29.6 & 17.0 & 0.152 \\
\hline Pancreatic Ab (\%) $(n=150)$ & 79.4 & 8.1 & $<0.001$ \\
\hline HLA DR $3 / 4(\%)(n=91)$ & 60.7 & 40.0 & 0.118 \\
\hline
\end{tabular}

Values are presented as mean \pm standard deviation unless otherwise indicated.

T1DM, type 1 diabetes mellitus; T2DM, type 2 diabetes mellitus; $\mathrm{HbA} 1 \mathrm{c}$, hemoglobin A1c; $\mathrm{HCO} 3$, bicarbonate; BEECF, base excess in extracellular fluid; DKA, diabetic ketoacidosis; HLA, human leukocyte antigen.

${ }^{a)}$ The participant number of arterial blood gas analysis: T1DM, 104; T2DM, 83. 'We marked positive if at least one of anti-GAD, IAA, IA-2, and ICA 512 was positive. hospitals (Fig. 1). Among them, 137 children (61.4\%) were initially classified as having T1DM at diagnosis; the remaining 86 children (38.6\%) were diagnosed with T2DM. Of the 223 children with diabetes, 5 (2.2\%) had a subsequent change in type of diabetes, based on pancreatic autoantibody, HLA typing, and clinical courses. One of 137 children initially classified as T1DM was reclassified as having T2DM, and 4 of 86 children with T2DM at diagnosis were reclassified as having T1DM.

\section{Clinical and laboratory characteristics of T1DM and T2DM}

The clinical and laboratory characteristics of the 223 children with diabetes are shown in Table 1 . The mean age at diagnosis in children with T1DM was $10.1 \pm 4.0$ years; this age was significantly lower than that of children with T2DM (10.1 \pm 4.0 years vs. $14.0 \pm 2.3$ years, $P<0.001$ ). The mean $\mathrm{BMI}$ of the children with T2DM was significantly higher than that of children of T1DM $\left(24.6 \pm 4.2 \mathrm{~kg} / \mathrm{m}^{2}\right.$ vs. $\left.16.5 \pm 3.6 \mathrm{~kg} / \mathrm{m}^{2}, P<0.001\right)$. Children with T1DM were less likely to have a family history of T2DM (29.5\% vs. 57.3\%), more likely to have typical diabetic symptoms (polyuria, polydipsia, weight loss) and diabetic ketoacidosis (DKA) (38.6\% vs. 2.4\%), and have higher serum HbAlc levels (12.1\% vs. 10.7\%). Pancreatic autoantibodies and HLA typing were examined in 150 and 91 diabetic children, respectively. The prevalence of pancreatic autoantibody was higher in children with T1DM than in children with T2DM (79.4\% vs. $8.1 \%)$. However, there were no significant differences in the prevalence of thyroid antibodies and HLA-DR 3/4 between T1DM and T2DM.

\section{Relation between $\mathrm{C}$-peptide level and type of diabetes}

The serum C-peptide level was significantly higher in T2DM than T1DM (3.91 ng/mL vs. $0.80 \mathrm{ng} / \mathrm{mL}, P<0.001)$. A total of 140 children with T1DM had of C-peptide concentration range of $0.01-3.93 \mathrm{ng} / \mathrm{mL}$ (Fig. 2). Only 1 of them had a C-peptide level $\geq 3.0 \mathrm{ng} / \mathrm{mL}$, and $38.6 \%$ of patients had a C-peptide value $<0.6 \mathrm{ng} / \mathrm{mL}$. In contrast, 48 of 83 children with T2DM $(57.8 \%)$ had a C-peptide level $\geq 3.0 \mathrm{ng} / \mathrm{mL}$, and none had a C-peptide

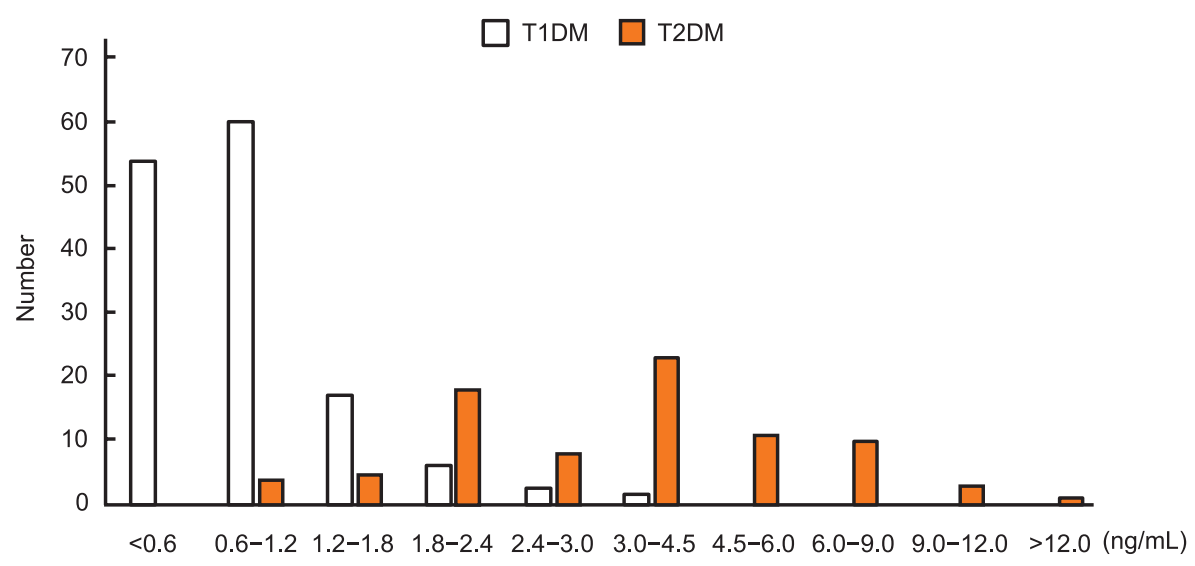

Fig. 2. Distribution of C-peptide level in type 1 (T1DM) and type 2 diabetes mellitus (T2DM). 
level $<0.6 \mathrm{ng} / \mathrm{mL}$. The proportion of children with T2DM increased in accordance with serum C-peptide level. The predictive value for T2DM is $6.3 \%$ ( $95 \%$ confidence interval [CI], 2-16) if the C-peptide level is between 0.6 and $1.2 \mathrm{ng} / \mathrm{mL}, 22.7 \%$ (95\% CI, 9-46) if between 1.2 and $1.8 \mathrm{ng} / \mathrm{mL}, 75.0 \%$ (95\% CI, $53-90$ ) if between 1.8 and $2.4 \mathrm{ng} / \mathrm{mL}, 80.0 \%$ (95\% CI, 44-96) if between 2.4 and $3.0 \mathrm{ng} / \mathrm{mL}, 95.8 \%$ (95\% CI, 77-100) if between 3.0 and $4.5 \mathrm{ng} / \mathrm{mL}$, and $100 \%$ if C-peptide level $\geq 4.5 \mathrm{ng} / \mathrm{mL}$.

Among 223 diabetic children, 5 had a subsequent change in type of diabetes. One of 137 children initially classified as having T1DM was changed to T2DM classification, and his initial serum C-peptide level was $1.5 \mathrm{ng} / \mathrm{mL}$. He had clinical symptoms of diabetes but he was negative for DKA and a family history of diabetes. Four of 86 children initially classified as having T2DM were subsequently reclassified as T1DM; their serum C-peptide levels were 1.3, 2.33, 2.73, and $3.93 \mathrm{ng} / \mathrm{mL}$, respectively. Two of them had pancreatic autoantibodies, 3 had typical clinical symptoms, and 1 had DKA at diabetes diagnosis. During follow-up, these patients' serum C-peptide levels gradually decreased to $0.66 \mathrm{ng} / \mathrm{mL}, 1.13 \mathrm{ng} / \mathrm{mL}, 0.37 \mathrm{ng} / \mathrm{mL}$, and 3.0 $\mathrm{ng} / \mathrm{mL}$, respectively.

\section{Discussion}

Major forms of DM are classified as T1DM and T2DM. T1DM is insulin-deficiency diabetes caused by pancreatic $ß$-cell destruction. T2DM is insulin-resistant diabetes that causes a relative insulin deficiency. The occurrence rate of T1DM is higher than that of T2DM in children and adolescents.

The treatment method, decision for insulin injection, and treatment start time depends on the type of DM. DM classification in clinical cases depends on age, clinical symptoms, ketonic acid presence in urine, obesity, family history, evidence of autoimmune disease, and serum C-peptide level. The patients with (1) younger age of onset, (2) clinical symptoms, (3) DKA presence, and (4) suspected autoimmune disease tend to be classified as T1DM. On the other hand, patients who (1) are obese, (2) have a family history of T2DM, (3) have few or no diabetic symptoms, (4) have insulin resistance tend to be classified as T2DM. However, it is difficult to classify DM in some cases, even though there are significant differences in each type. For instance, typical clinical symptoms for each DM type are not found, autoimmune features are found in T2DM, HLA type is not clearly distinguished, and the recent trend of child obesity is increasing ${ }^{11,12)}$.

C-peptide levels reflect the residual insulin secretion function of $\beta$ cells in the following manner: 1 molecule of proinsulin decomposes into 1 molecule of insulin and 1 molecule of C-peptide. As a result, measuring the C-peptide level is meaningful in diagnosing T1DM. The main cause of T1DM is disruption of $\beta$ cells by autoimmunity, which leads to decreased insulin secretion function ${ }^{13-16)}$. Because there was no largescale study in Korea about using specific C-peptide levels for classifying DM type, we undertook diverse research on the topic. This study is meaningful that it is the first large-scale epidemiologic study on this topic in Korea.

As shown in other studies, we also found typical characteristics of DM. In this study, T1DM age of onset was younger than in T2DM and T2DM BMI was higher than that in T1DM. Family history of T1DM was $29.5 \%$, whereas that of T2DM was $57.3 \%$. The clinical symptoms of polyuria, polydipsia, and weight loss were found more frequently in T1DM than in T2DM. T1DM DKA was $38.6 \%$, which was much higher than the $2.4 \%$ from T2DM. The positivity of pancreatic autoantibody and thyroid autoantibody was higher in T1DM than in T2DM.

In this study, the 54 patients whose initial C-peptide level was $<0.6 \mathrm{ng} / \mathrm{mL}$ were diagnosed with T1DM without exception. Except for 1 T1DM case whose C-peptide level was $3.93 \mathrm{ng} /$ $\mathrm{mL}$, the other 48 patients whose C-peptide level was $>3.0 \mathrm{ng} /$ $\mathrm{mL}$ were diagnosed with T2DM. In this study, the proportion of patients diagnosed with T2DM rose along increasing C-peptide levels; this result was quantified.

In this study, using C-peptide levels to classify DM type is different from the results of a 2012 Sweden study. According to Ludbigsson's homogeneous research ${ }^{6}$, the expected proportion of C-peptide level for T2DM is $0.1 \%$ if $<0.6 \mathrm{ng} / \mathrm{mL}, 2 \%$ if between 0.6 and $3.0 \mathrm{ng} / \mathrm{mL}$, and $46 \%$ if $>3.0 \mathrm{ng} / \mathrm{mL}$. This suggests that a considerable proportion of T1DM is found at the $<3.0 \mathrm{ng} / \mathrm{mL}$ interval $\left.^{6}\right)$ for the following reasons. First, the Swedish study used random C-peptide levels instead of fasting C-peptide levels. This could cause a raised C-peptide level, which affects the result that T1DM is found among those with a high C-peptide level. Fasting C-peptide level correlate well with late postprandial serum C-peptide level, but overnight fast is preferred for purposes of standardization and more routinely used $^{14,17)}$. Second, there is difference in ethnic groups. Diabetes prevalence rate and type ratio are different between Korean and Swedish patients. T1DM is diagnosed in 40 of 0.1 million people in northern Europe, whereas 1.14 of 0.1 million are diagnosed in Korea and Japan ${ }^{18)}$. In Swedish pediatric patients, 93\% of patients have T1DM and only $1.9 \%$ have T2DM, whereas about $60 \%-70 \%$ have T1DM in Korea ${ }^{19,20)}$. In Korea, only 50\%-60\% of cases report autoimmune positivity; however, this level is $70 \%-90 \%$ in other countries ${ }^{21-23}$. Obesity causing T2DM is $80 \%$ of T2DM in Western countries, whereas the majority of T2DM is not caused by obesity in Korea. DKA positivity is present in only $17 \%$ Swedish patients. Accordingly, other ethnic groups DM characteristics are different ${ }^{6)}$.

In our study, 5 cases changed DM type while undergoing medical treatment: 4 from T2DM to T1DM and 1 from T1DM to T2DM, showing that characteristics of T1DM coexist with those of T2DM. These facts make it hard to classify DM type. In the 4 cases that changed from T2DM to T1DM, their initial C-peptide levels were 1.3, 2.3, 2.7, and $3.93 \mathrm{ng} / \mathrm{mL}$. Three of these patients had clinical symptoms of diabetes, 1 presented with obesity, and 1 had a family history of DM. There was uncertainty about T2DM classification in these patients, and they were classified as T1DM because serologic markers can be confusing. However, they constantly needed insulin treatment and, later, their average C-peptide levels gradually decreased to 
$0.66,1.1,0.37$, and $3.0 \mathrm{ng} / \mathrm{mL}$, respectively. As a result, their final classification was changed to T1DM. In 1 case of change from T1DM to T2DM, the patient's initial C-peptide level was $1.5 \mathrm{ng} /$ $\mathrm{mL}$, and the patient had clinical symptoms of diabetes and was obese, but was negative for DKA and family history of DM. This patient was initially classified as having T1DM based on the clinical symptoms, but final classification was changed to T2DM because the subsequent C-peptide level was $3.5 \mathrm{ng} / \mathrm{mL}$. Thus the additional measurement of $\mathrm{C}$-peptide level is important to include because there is an expected proportion of T2DM in accordance with C-peptide level.

There are some limitations to this study. First, it is a retrospective study based on medical records, which can cause errors. Second, this study is a multicenter study with different clinicians. Third, factors that can affect C-peptide levels, such as infection, are unknown ${ }^{24}$. Fourth, the number of participants is low. The Swedish study included 2,734 patients. It is difficult to conclude that the differences in this study were caused only by different characteristics of the ethnic groups; thus, further joint research and epidemiologic studies with large number of patients in Korea is required. Fifth, this study is undertook for 11 years, which is relatively long period than 4 years of Swedish study. Long research period could affect on consistency of cases.

In conclusion, it is not easy to determine the DM type in initially diagnosed diabetes patients for several reasons: atypical clinical symptoms of each DM type, autoimmune features found in T2DM, aspecific HLA type, and the increasing trend of child obesity. But serum C-peptide level measured at initial diabetes diagnosis is significantly useful for classifying DM type and choosing the appropriate treatment method.

\section{Conflict of interest}

No potential conflict of interest relevant to this article was reported.

\section{References}

1. Daneman D. Type 1 diabetes. Lancet 2006;367:847-58.

2. Gungor N, Hannon T, Libman I, Bacha F, Arslanian S. Type 2 diabetes mellitus in youth: the complete picture to date. Pediatr Clin North Am 2005;52:1579-609.

3. Harron KL, Feltbower RG, McKinney PA, Bodansky HJ, Campbell FM, Parslow RC. Rising rates of all types of diabetes in south Asian and non-south Asian children and young people aged 0-29 years in West Yorkshire, U.K., 19912006. Diabetes Care 2011;34:652-4.

4. American Diabetes Association. Type 2 diabetes in children and adolescents. Pediatrics 2000;105(3 Pt 1):671-80.

5. Katz LE, Jawad AF, Ganesh J, Abraham M, Murphy K, Lipman TH. Fasting c-peptide and insulin-like growth factor-binding protein-1 levels help to distinguish childhood type 1 and type 2 diabetes at diagnosis. Pediatr Diabetes 2007;8:53-9.

6. Ludvigsson J, Carlsson A, Forsander G, Ivarsson S, Kockum
I, Lernmark A, et al. C-peptide in the classification of diabetes in children and adolescents. Pediatr Diabetes 2012;13:45-50.

7. Hattersley A, Bruining J, Shield J, Njolstad P, Donaghue K; International Society for Pediatric and Adolescent Diabetes. ISPAD Clinical Practice Consensus Guidelines 2006-2007. The diagnosis and management of monogenic diabetes in children. Pediatr Diabetes 2006;7:352-60.

8. Pearson ER, Starkey BJ, Powell RJ, Gribble FM, Clark PM, Hattersley AT. Genetic cause of hyperglycaemia and response to treatment in diabetes. Lancet 2003;362:127581.

9. Byrne MM, Sturis J, Fajans SS, Ortiz FJ, Stoltz A, Stoffel M, et al. Altered insulin secretory responses to glucose in subjects with a mutation in the MODY1 gene on chromosome 20. Diabetes 1995;44:699-704.

10. Besser RE. Determination of C-peptide in children: when is it useful? Pediatr Endocrinol Rev 2013;10:494-502.

11. Report of the Expert Committee on the Diagnosis and Classification of Diabetes Mellitus. Diabetes Care 1997;20:1183-97.

12. D'Adamo E, Caprio S. Type 2 diabetes in youth: epidemiology and pathophysiology. Diabetes Care 2011;34 Suppl 2:S161-5.

13. Garcia-Webb P, Bonser A, Welborn TA. Correlation between fasting serum C-peptide and B cell insulin secretory capacity in diabetes mellitus. Diabetologia 1982;22:296.

14. Webb PG, Bonser AM. Basal C-peptide in the discrimination of type I from type II diabetes. Diabetes Care 1981;4:616-9.

15. Service FJ, Rizza RA, Zimmerman BR, Dyck PJ, O'Brien PC, Melton LJ 3rd. The classification of diabetes by clinical and C-peptide criteria. A prospective population-based study. Diabetes Care 1997;20:198-201.

16. Hother-Nielsen O, Faber O, Sorensen NS, Beck-Nielsen $\mathrm{H}$. Classification of newly diagnosed diabetic patients as insulin-requiring or non-insulin-requiring based on clinical and biochemical variables. Diabetes Care 1988;11:531-7.

17. Gjessing HJ, Matzen LE, Froland A, Faber OK. Correlations between fasting plasma C-peptide, glucagon-stimulated plasma C-peptide, and urinary C-peptide in insulin-treated diabetics. Diabetes Care 1987;10:487-90.

18. The Korean Society of Pediatric Endocrinology. Pediatric endocrinology. Seoul: Kwangmoon Press, 1996.

19. Park J, Oh J, Yu J. Autoantibody positivity and clinical characteristics of diabetes mellitus in childhood. J Korean Soc Pediatr Endocrinol 2011;16:119-27.

20. Hur J, Lee HS, Hwang JS. Clinical characteristics of type 1 diabetes mellitus at initial Diagnosis. J Korean Soc Pediatr Endocrinol 2006;11:177-84.

21. Lee CW, Shin HJ, Kim DH. Prevalence of autoimmune antibodies in type i diabetic children and their siblings. J Korean Soc Pediatr Endocrinol 1999;4:78-87.

22. Hong EH, Park JS, Lee HS, Cho MH, Ko CW. Clinical 
characteristics and laboratory findings of children who were newly diagnosed with diabetes mellitus (from 2001 to 2008). J Korean Soc Pediatr Endocrinol 2009;14:110-5.

23. Yu J, Shin CH, Yang SW, Park MH, Eisenbarth GS. Analysis of children with type 1 diabetes in Korea: high prevalence of specific anti-islet autoantibodies, immunogenetic similarities to Western populations with "unique" haplotypes, and lack of discrimination by aspartic acid at position 57 of DQB. Clin Immunol 2004;113:318-25.

24. Ludvigsson J, Heding LG. C-peptide in children with juvenile diabetes: a preliminary report. Diabetologia 1976;12:627-30 